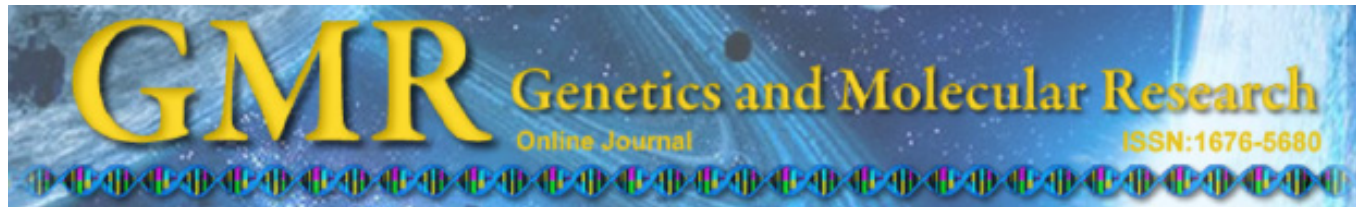

\title{
In vitro genotoxicity assessment of caffeic, cinnamic and ferulic acids
}

\author{
E.L. Maistro ${ }^{1}$, J.P.F. Angeli ${ }^{2}$, S.F. Andrade ${ }^{3}$ and M.S. Mantovani ${ }^{2}$ \\ ${ }^{1}$ Departamento de Fonoaudiologia, Faculdade de Filosofia e Ciências, \\ Universidade Estadual Paulista, UNESP, Marília, SP, Brasil \\ ${ }^{2}$ Departamento de Biologia Geral, Universidade Estadual de Londrina, \\ Londrina, PR, Brasil \\ ${ }^{3}$ Núcleo de Investigações Químico-Farmacêuticas, \\ Universidade do Vale do Itajaí, Itajaí, SC, Brasil \\ Corresponding author: E.L. Maistro \\ E-mail: edson.maistro@marilia.unesp.br
}

Genet. Mol. Res. 10 (2): 1130-1140 (2011)

Received January 18, 2011

Accepted February 10, 2011

Published June 14, 2011

DOI 10.4238/vol10-2gmr1278

\begin{abstract}
Phenols are a large and diverse class of compounds, many of which occur naturally in a variety of food plants; they exhibit a wide range of biological effects, including antibacterial, antiinflammatory, antiallergic, hepatoprotective, antithrombotic, antiviral, anticarcinogenic, and vasodilatory actions. We examined the genotoxic and clastogenic potential of three phenolic compounds: caffeic, cinnamic and ferulic acids, using the comet and micronucleus assays in vitro. Drug-metabolizing rat hepatoma tissue cells (HTCs) were used. Three different concentrations $(50,500$ and $1500 \mu \mathrm{M})$ of these phenolic acids were tested on the HTCs for $24 \mathrm{~h}$. The caffeic, cinnamic and ferulic acids were not genotoxic by the comet assay $(\mathrm{P}>0.05)$. However, the micronucleus test showed an increase in the frequency of micronucleated cells for the three compounds, indicating that these substances have clastogenic effects in HTC.
\end{abstract}

Key words: Caffeic acid; Cinnamic acid; Ferulic acid; Comet assay; Micronucleus test; Clastogenic effects 


\section{INTRODUCTION}

Phenolic acids are plant metabolites that are widely found throughout the plant kingdom. They are essential for the growth and reproduction of plants, and are produced as a defence mechanism against pathogens. Phenolic compounds are considered to be potential therapeutic agents against a wide range of ailments including neurodegenerative diseases, cancer, diabetes, coronary heart dysfunction, inflammatory diseases, and ageing (Ferguson, 2001; Soobrattee et al., 2005), and there is growing interest in their strong antioxidant activity (Srinivasan et al., 2007).

Caffeic acid (CA) is a naturally occurring phenolic compound, and its derivative caffeic acid phenethyl ester is found in many fruits, vegetables, and plants, including coffee, although the amounts vary greatly depending on the plant (Chung et al., 2004). An important source of these substances is propolis from bee hives, which contain, as prominent constituents, two distinct series of polyphenols, i.e., flavonoids and caffeic acid esters (Greenaway et al., 1987). Sestili et al. (2002) reported that the most prominent activity of CA is that it prevents DNA single-strand breakage and cytotoxicity. It also has the ability to chelate iron. Caffeic acid has antiviral, anti-inflammatory and immunomodulatory properties (Grunberger et al., 1988) and has been shown to inhibit the growth of different types of transformed cells (Burke Jr. et al., 1995). The mutagenicity of CA was evaluated by the Ames test with negative results for both, with and without metabolizing S9 fractions (Fung et al., 1988). On the other hand, Hanham et al. (1983) reported clastogenic activity in Chinese hamster ovary cells and Hirose et al. (1997) observed that CA slightly increased incidences of forestomach papillomas in rats.

Cinnamic acid (CI) is a key intermediary in the shikimate and phenylpropanoid pathways. Phenylpropanoids are a class of plant metabolites based on phenylalanine. Phenylalanine is first converted into cinnamates, coumarines, caffeic acids, ferulic acids, and sinapic acids. CI, which is the precursor of these acids, is the parent compound of its esters, which are more volatile enabling them to be transported to other parts more easily. Cinnamic acid and its derivatives, including esters and carboxylic functional derivatives, are important components in flavorings, perfumes, synthetic dyes, and pharmaceuticals (Natella et al., 1999; Bickers et al., 2005). CI is not acutely toxic by the dermal route of exposure, while cinnamaldehyde has low toxicity by the dermal route (RIFM, 1976, 1997). The mutagenicity of CI was evaluated in Salmonella typhimurium, Escherichia coli and by the Rec assay in Bacillus subtilis, and no evidence of mutagenicity was found (Sekizawa and Shibamoto, 1982; Kuroda et al., 1984; Azizan and Blevins, 1995).

Ferulic acid (FA) is a phenolic acid plant constituent that is the result of the metabolism of phenylalanine and tyrosine. It occurs primarily in the seeds and leaves, both in its free form and is covalently linked to lignin and other biopolymers. In wheat, FA is an ester, which is linked to cell wall carbohydrates and occurs in higher concentrations in the alcurone, pericarp and embryo cell walls (Fulcher, 1983). FA is also a major constituent of fruits (e.g., orange), certain vegetables (e.g., tomato, carrot), and sweet corn (Sri et al., 2003). Due to its phenolic nucleus and an extended side chain conjugation, it readily forms a resonance stabilized phenoxy radical, which accounts for its potent antioxidant potential. Ultraviolet (UV) absorption by FA catalyzes stable phenoxy radical formation, thereby giving it the ability to terminate free radical chain reactions. By virtue of effectively scavenging deleterious radicals and suppressing radiation-induced oxidative reactions, FA may have an important antioxidant 
function in preserving the physiological integrity of cells exposed to both air and impinging UV radiation. FA has similar photoprotection properties, offering skin protection when dissolved in cosmetic lotions. When added to foods, it inhibits lipid peroxidation and subsequent oxidative spoilage. By the same mechanism, FA may protect against various inflammatory diseases. A number of other industrial applications are based on the antioxidant potential of FA (Graf, 1992; Kanski et al., 2002).

Despite the commercial and therapeutic potential of the caffeic, cinnamic and ferulic acids, so far there have very little studies on the possible genotoxic effects of these natural compounds on mammalian cells. Therefore, the objective of the present study was to evaluate the genotoxic and clastogenic potential of these three phenolic compounds in cultured mammalian cells, where genetic damage was measured by the comet and micronucleus assays in the presence of drug-metabolizing rat hepatoma tissue cells (HTCs).

\section{MATERIAL AND METHODS}

\section{Chemical agents}

Caffeic, cinnamic and ferulic acids were purchased from Acros Organics (Geel, Belgium), and diluted in dimethyl-sulfoxide (DMSO; CAS: 67-68-5, Merck Chemicals, SP, Brazil) for use in the experiments. The final concentration of DMSO did not exceed $1 \%$ in any of the protocols performed. The indirect adduct forming agent benzo[a]pyrene was used as the DNA damaging agent (positive control) (CAS: 50-32-8, Fluka). It was diluted in DMSO and used at a concentration of $20 \mu \mathrm{M}$ (concentration established in a pilot experiment - data not shown). Cytochalasin-B (Cyt-B; CAS: 14930-96-2, Sigma) was diluted in DMSO to obtain a stock solution of $300 \mu \mathrm{g} / \mathrm{mL}$, which was kept at $4^{\circ} \mathrm{C}$ in the dark, until use. The other main chemicals used were obtained from the following suppliers: normal melting point (NMP) agarose: Roth, Karlsruhe, Germany; low melting point (LMP) agarose (CAS: 9012-36-6, FMC, Rockland, MD, USA); sodium $N$-lauroyl sarcosine (CAS: 7631-98-3), and ethylenediaminetetraacetic acid (EDTA) (CAS: 60-00-4, Sigma).

\section{Cell viability}

Cell viability was determined by 3-(4,5-dimethyl-2-thiazolyl)-2,5-diphenyl-2H-tetrazolium bromide (MTT) assay (Mosmann, 1983) as reflected by the activity of succinate dehydrogenase. HTCs $\left(3 \times 10^{4}\right.$ per well) were plated in 96-well microplates. Following incubation with phenolic acids $(0-1500 \mu \mathrm{M})$ for $24 \mathrm{~h}$, MTT $(100 \mu \mathrm{L}, 0.5 \mathrm{mg} / \mathrm{mL})$ was added to each well, and the plate was incubated at $37^{\circ} \mathrm{C}$ for $4 \mathrm{~h}$. The medium was then removed and replaced with 100 $\mu \mathrm{L}$ DMSO to dissolve the formazan crystals. The product was quantified spectrophotometrically, by measuring absorbance at $570 \mathrm{~nm}$ using a microplate reader. Cells without phenolic acid treatment served as negative control and doxorubicin as positive control (Figure 1).

\section{Culture and cell treatments}

The hepatoma cell line from Rattus norvegicus, HTC, which expresses phase I and phase II drug-metabolizing enzymes (henceforth called the drug-metabolizing cell line), was 
obtained from the Rio de Janeiro Cell Bank (RJCB). The stability of the HTC ploidy is periodically checked by RJCB and by several studies of our research group. Cells were grown in $5.0 \mathrm{~mL}$ DMEM/F12 culture medium (Gibco ${ }^{\circledR}$, Brazil), supplemented with $10 \%$ fetal bovine serum $\left(\mathrm{Gibco}^{\circledR}\right)$. Cells were cultivated as monolayers in $25-\mathrm{cm}^{2}$ flasks, at an initial concentration of $1.0 \times 10^{6}$ cells per flask in a BOD-type incubator at $37^{\circ} \mathrm{C}$. Under these conditions, the length of the cell cycle was $24 \mathrm{~h}$. The cells were cultivated for one complete cycle prior to treatment with fresh complete medium containing the test substances. Caffeic, cinnamic and ferulic acids were tested at concentrations of 50,500 and $1500 \mu \mathrm{M}$. Benzo[a]pyrene was used as the positive control treatment at a final concentration of $20 \mu \mathrm{M}$, and one culture treated with the solvent DMSO served as the negative control in each experiment. Treatment with the substances was carried out for $24 \mathrm{~h}$. The cells were washed twice with PBS after each treatment. All cell treatments were repeated three times.

\section{Comet assay}

The general procedure was carried out by the method described by Uhl et al. (1999, 2000), based on the premises proposed by Tice et al. (2000). HTCs in the early log-phase were trypsinized $(0.1 \%)$ and seeded $2 \times 10^{5}$ cells/well in plates of 24 wells (TPP), and incubated for another $24 \mathrm{~h}$ after performing the treatments with the test substance, as described above. At the end of the treatments, the cells were washed twice with $5 \mathrm{~mL}$ ice-cold PBS, pH 7.4, and trypsinized with $0.2 \mathrm{~mL}$ in a $0.025 \%$ solution. After about $2 \mathrm{~min}$, this process was terminated by adding complete culture medium. The cells were collected by centrifugation at $900 \mathrm{rpm}$ for $5 \mathrm{~min}$, and the pellet was gently resuspended in $1 \mathrm{~mL}$ culture medium. A $20-\mu \mathrm{L}$ aliquot of the cell suspension was mixed with $100 \mu \mathrm{L} 0.5 \% \mathrm{LMP}$ agarose at $37^{\circ} \mathrm{C}$, and immediately spread onto microscope slides pre-coated with 1.5\% NMP agarose. Coverslips were added and the slides were allowed to gel at $4^{\circ} \mathrm{C}$ for $20 \mathrm{~min}$. The coverslips were gently removed and the slides were then immersed in cold, freshly prepared lysing solution consisting of $89 \mathrm{~mL}$ of a stock solution $(2.5 \mathrm{M} \mathrm{NaCl}, 100 \mathrm{mM}$ EDTA, $10 \mathrm{nM}$ Tris, $\mathrm{pH}$ set to 10.0 with $\sim 8 \mathrm{~g}$ solid $\mathrm{NaOH}, 890 \mathrm{~mL}$ distilled water and $1 \%$ sodium lauroyl sarcosine), plus $1 \mathrm{~mL}$ Triton X-100 (Merck) and $10 \mathrm{~mL}$ DMSO. The slides were left to stand for $1 \mathrm{~h}$ at $4^{\circ} \mathrm{C}$, protected from light. They were then placed in the gel box, positioned at the anode end, and left for $20 \mathrm{~min}$ at $4^{\circ} \mathrm{C}$, prior to electrophoresis, in a high $\mathrm{pH}(>13)$ electrophoresis buffer $(300 \mathrm{mM} \mathrm{NaOH}$ per $1 \mathrm{mM}$ EDTA prepared from a stock solution of $10 \mathrm{~N} \mathrm{NaOH}$ and $200 \mathrm{mM}$ EDTA, $\mathrm{pH}$ 10.0) to allow the DNA to unwind. Electrophoresis was performed in an ice bath $\left(4^{\circ} \mathrm{C}\right)$ for 20 min at $25 \mathrm{~V}$ and $300 \mathrm{~mA}(0.722 \mathrm{~V} / \mathrm{cm})$. The slides were then submerged in a neutralization buffer $(0.4 \mathrm{M}$ Tris- $\mathrm{HCl}, \mathrm{pH}$ 7.5) for $15 \mathrm{~min}$, dried at room temperature and fixed in $100 \%$ ethyl alcohol for $10 \mathrm{~min}$. The slides were dried and stored at least overnight before staining.

For staining, the slides were briefly rinsed in distilled water, covered with $30 \mu \mathrm{L} 1 \mathrm{X}$ ethidium bromide-staining solution prepared from a 10X stock $(200 \mu \mathrm{g} / \mathrm{mL})$ and covered with a coverslip. The material was evaluated immediately at $400 \mathrm{X}$ magnification, using a fluorescence microscope (Olympus) with a 515-560-nm excitation filter and a 590-nm barrier filter.

\section{Cytokinesis-micronucleus assay}

The cytokinesis-block micronucleus assay was performed according to the protocol of 
Natarajan and Darroudi (1991). Test agents were added to $5 \mathrm{~mL}$ fresh medium at $24 \mathrm{~h}$ (one cell cycle) after initiating the culture of HTCs, which had been previously seeded in the complete culture medium and stabilized in $25-\mathrm{cm}^{2}$ flasks, as described. Each of the substances used in the treatments cited above (negative control, positive control, phenolic acids tested at concentrations of 50,500 and $1500 \mu \mathrm{M}$ ) were applied for $24 \mathrm{~h}$. At the end of the treatments, the cells were washed twice with $5 \mathrm{~mL}$ ice-cold PBS, $\mathrm{pH} 7.4$, and Cyt-B was added to fresh complete culture medium to obtain a final concentration of $3 \mu \mathrm{g} / \mathrm{mL}$. It was continually used for $28 \mathrm{~h}$ to block cytokinesis and yield binucleated cells. All assays described here were repeated independently three times.

The procedures used for harvesting, slide preparation and staining were based on Salvadori et al. (1993). At harvest time, the cells were rinsed twice with $5 \mathrm{~mL} \mathrm{PBS,} \mathrm{pH} \mathrm{7.4,} \mathrm{trypsi-}$ nized $(0.025 \%$ trypsin) and centrifuged for $5 \mathrm{~min}$ at $900 \mathrm{rpm}$. The pellet was resuspended in ice-cold hypotonic solution ( $1 \%$ sodium citrate) plus one drop $40 \%$ formaldehyde and then carefully homogenized with a Pasteur pipette. This cell suspension was centrifuged under the same conditions and the pellet resuspended in methanol:acetic acid (3:1), and once again homogenized with a Pasteur pipette. The cell suspension was then centrifuged and resuspended in $1.5 \mathrm{~mL}$ methanol:acetic acid (3:1). The fixed cells were then dropped onto slides previously cleaned and covered with a film of ice-cold distilled water. They were stained in $2 \%$ Giemsa dissolved in phosphate buffer $\left(0.06 \mathrm{M} \mathrm{Na}_{2} \mathrm{HPO}_{4}\right.$ and $\left.0.039 \mathrm{M} \mathrm{KH}_{2} \mathrm{PO}_{4}, \mathrm{pH} 7.0\right)$ for $10 \mathrm{~min}$, washed with water, dried and kept at $4^{\circ} \mathrm{C}$ until microscopic analysis.

\section{Frequencies, scoring procedures and data evaluation}

The extent and distribution of DNA damage indicated by the comet assay were evaluated by examining at least 100 randomly selected and non-overlapping cells on the slides, per treatment. These cells were scored visually according to tail size into four classes: 1 ) class 0 : undamaged, without a tail; 2) class 1: with a tail shorter than the diameter of the head (nucleus); 3) class 2: with a tail length one or twice the diameter of the head, and 4) class 3: with a tail longer than twice the diameter of the head (Kobayashi et al., 1995). Apoptotic cells with totally fragmented nuclei were not considered in the analysis (Speit and Hartmann, 2005). The total score for 100 comets was obtained by multiplying the number of cells in each class by the damaged class, which ranged from 0 (all undamaged) to 300 (all maximally damaged).

To evaluate micronucleus induction, one thousand binucleated cells with well-preserved cytoplasm were scored per coded slide in each experimental repetition. The criteria for the identification of binucleated cells and micronuclei (Titenko-Holland et al., 1997) were as follows: a) both nuclei and micronuclei should be round; b) micronuclei should be smaller than one-third of the main nuclei; c) micronuclei must not touch the main nuclei; d) micronuclei must not be refractive and should be of the same color and intensity as the main nuclei. To avoid the influence of cytotoxic effects in the determination of micronuclei, the nuclear division index (NDI) was calculated for each experimental point. Five hundred viable cells were scored for each culture to determine the average of cells with 1,2,3, and 4 nuclei and calculate the NDI using the formula: NDI $=(\mathrm{M} 1+2(\mathrm{M} 2)+3(\mathrm{M} 3)+4(\mathrm{M} 4)) / N$, where M1-M4 represent the number of cells with one to four nuclei and $N$ is the total number of viable cells scored (Eastmond and Tucker, 1989). The results of the three independent tests were totaled and statistically analyzed. 
The data obtained from the comet and micronucleus assays were submitted to the oneway analysis of variance (ANOVA) and the Tukey multiple comparison test (Sokal and Rohlf, 1995), using the GraphPad Instat ${ }^{\mathbb{B}}$ software (version 3.01). The results were considered to be statistically significant at $\mathrm{P}<0.05$.

\section{RESULTS}

Regarding the ability of phenolic acid to influence cell viability by the MTT test, none of the compounds tested presented significant toxic effect in the concentrations assayed ( 1 to $1500 \mu \mathrm{M})($ Figure 1).

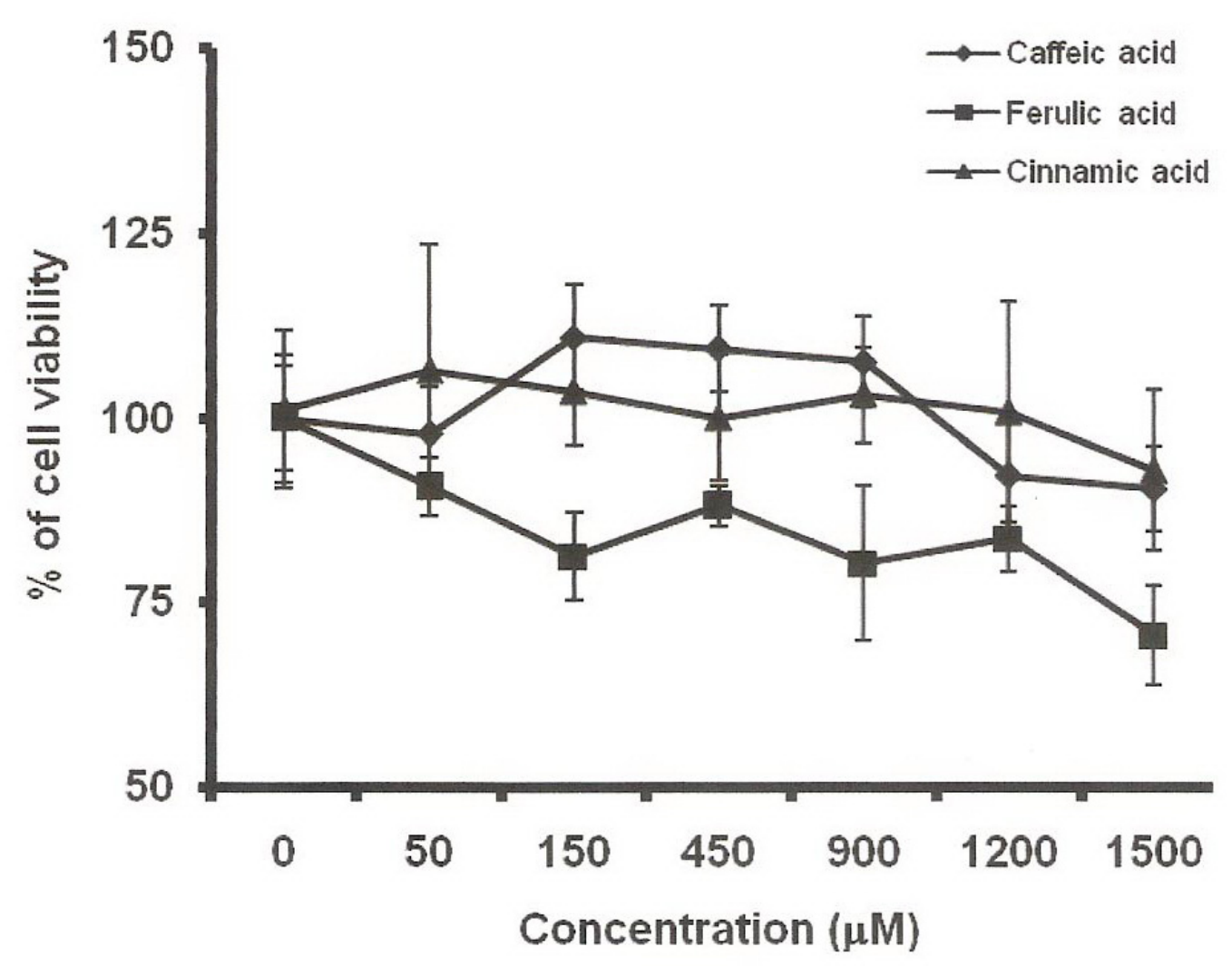

Figure 1. Cell viability indices for the three phenolic acids.

The results obtained for the genotoxicity assessment of caffeic, cinnamic and ferulic acids in HTCs by the comet assay are shown in Table 1. None of the three phenolic acids tested showed statistically significant increases in the total damaged cells and scores in the doses tested, compared with the negative control group. An increase in the total damaged cells was observed for the higher dose $(1500 \mu \mathrm{M})$ of the compounds tested, but without statistical significance. 


\begin{tabular}{|c|c|c|c|c|c|c|}
\hline \multirow[t]{2}{*}{ Treatments (total repetitions) } & \multirow[t]{2}{*}{ Total damaged cells } & \multicolumn{4}{|c|}{ Comet class } & \multirow[t]{2}{*}{ Scores } \\
\hline & & 0 & 1 & 2 & 3 & \\
\hline $\begin{array}{l}\text { DMSO } \\
\text { (negative control) }\end{array}$ & $10.6 \pm 3.78$ & 89.3 & 10.3 & 0.3 & 0 & $11.0 \pm 4.3$ \\
\hline $\begin{array}{l}\text { Benzo[a]pyrene }(20 \mu \mathrm{M}) \\
\text {-positive control) }\end{array}$ & $89.3 \pm 6.11^{*}$ & 10.6 & 69.3 & 18.0 & 2 & $111.3 \pm 3.7^{*}$ \\
\hline \multicolumn{7}{|l|}{ Caffeic acid } \\
\hline $50 \mu \mathrm{M}$ & $6.33 \pm 3.05$ & 93.6 & 6.3 & 0 & 0 & $6.33 \pm 3.0$ \\
\hline $500 \mu \mathrm{M}$ & $5.0 \pm 2.0$ & 95.0 & 5.0 & 0 & 0 & $5.0 \pm 2.0$ \\
\hline $1500 \mu \mathrm{M}$ & $16.0 \pm 5.29$ & 84.0 & 13.6 & 2.3 & 0 & $18.3 \pm 6.8$ \\
\hline \multicolumn{7}{|l|}{ Cinnamic acid } \\
\hline $50 \mu \mathrm{M}$ & $5.66 \pm 3.21$ & 94.3 & 5.6 & 0 & 0 & $5.66 \pm 3.2$ \\
\hline $500 \mu \mathrm{M}$ & $7.66 \pm 5.50$ & 92.3 & 7.6 & 0 & 0 & $7.66 \pm 5.5$ \\
\hline $1500 \mu \mathrm{M}$ & $18.0 \pm 13.8$ & 82.0 & 16.3 & 1.6 & 0 & $19.6 \pm 16.7$ \\
\hline \multicolumn{7}{|l|}{ Ferulic acid } \\
\hline $50 \mu \mathrm{M}$ & $15.3 \pm 11.0$ & 84.6 & 15.0 & 0.3 & 0 & $15.6 \pm 11.5$ \\
\hline $500 \mu \mathrm{M}$ & $8.66 \pm 2.51$ & 91.3 & 8.6 & 0 & 0 & $8.6 \pm 2.5$ \\
\hline $1500 \mu \mathrm{M}$ & $23.0 \pm 3.6^{*}$ & 77.0 & 20.6 & 2.3 & 0 & $25.3 \pm 4.0$ \\
\hline
\end{tabular}

Data are reported as means \pm SD. DMSO = dimethyl-sulfoxide. *Significantly different from the negative control $(\mathrm{P}<0.05)$.

The results of experiments designed to assess the clastogenicity of the three phenolic acids in HTCs are shown in Table 2. The effects of phenolic compounds on nuclear division showed that only exposure to concentration of $1500 \mu \mathrm{M}$ caffeic and ferulic acids resulted in some decrease in the cell division; however, the differences were not statistically significant $(\mathrm{P}>0.05)$. The results obtained in the micronucleus test demonstrated a dose-related increase in the number of the micronucleated cells for the three substances tested, which was at least three times higher than that observed in the negative control group, for all the doses tested. This increase was not statistically significant at the dose of $50 \mu \mathrm{M}$ for caffeic and ferulic acids.

\begin{tabular}{|c|c|c|c|c|}
\hline \multirow[t]{2}{*}{ Treatments } & \multirow{2}{*}{$\begin{array}{c}\mathrm{NDI} / 1500 \text { cells } \\
(\text { mean } \pm \mathrm{SD})\end{array}$} & \multirow[t]{2}{*}{ Number of cells analyzed } & \multicolumn{2}{|c|}{ MN } \\
\hline & & & Number & $\%$ \\
\hline $\begin{array}{l}\text { DMSO } \\
\text { (negative control) }\end{array}$ & $1.48 \pm 0.02$ & 3000 & 22 & 0.73 \\
\hline $\begin{array}{l}\text { Benzo[a]pyrene }(20 \mu \mathrm{M}) \\
\text { (positive control) }\end{array}$ & $1.50 \pm 0.02$ & 3000 & $75^{*}$ & 2.50 \\
\hline \multicolumn{5}{|l|}{ Caffeic acid } \\
\hline $50 \mu \mathrm{M}$ & $1.46 \pm 0.05$ & 3000 & 50 & 1.66 \\
\hline $500 \mu \mathrm{M}$ & $1.44 \pm 0.01$ & 3000 & $98^{*}$ & 3.26 \\
\hline $1500 \mu \mathrm{M}$ & $1.15 \pm 0.03$ & 3000 & $119^{*}$ & 3.96 \\
\hline \multicolumn{5}{|l|}{ Cinnamic acid } \\
\hline $50 \mu \mathrm{M}$ & $1.57 \pm 0.05$ & 3000 & $68^{*}$ & 2.26 \\
\hline $500 \mu \mathrm{M}$ & $1.39 \pm 0.08$ & 3000 & $77 *$ & 2.56 \\
\hline $1500 \mu \mathrm{M}$ & $1.48 \pm 0.03$ & 3000 & $78^{*}$ & 2.60 \\
\hline \multicolumn{5}{|l|}{ Ferulic acid } \\
\hline $50 \mu \mathrm{M}$ & $1.60 \pm 0.01$ & 3000 & 63 & 2.10 \\
\hline $500 \mu \mathrm{M}$ & $1.37 \pm 0.01$ & 3000 & $66^{*}$ & 2.20 \\
\hline $1500 \mu \mathrm{M}$ & $1.54 \pm 0.03$ & 3000 & $95^{*}$ & 3.16 \\
\hline
\end{tabular}

$\mathrm{NDI}=$ nuclear division index; $\mathrm{DMSO}=$ dimethyl-sulfoxide; $\mathrm{MN}=$ micronucleus. $*$ Significantly different from the negative control $(\mathrm{P}<0.05)$. The increased frequencies of micronuclei represent cells with only a single micronuclei. 


\section{DISCUSSION}

In this study, the possibility of the DNA damage and micronucleus induction by CA, $\mathrm{CI}$ and FA phenolic acids, i.e., genotoxic and clastogenic activity, were investigated. Regarding the ability of phenolic acid to influence cell viability, none of the compounds tested presented significant toxic effect in the concentrations assayed (1 to $1500 \mu \mathrm{M})$. Viability was assayed as the ability of mitochondrial enzyme succinate dehydrogenase to reduce MTT to its corresponding formazan. The determination of cell viability after treatment is of importance when further assaying DNA damage, in order to avoid DNA fragmentation due to apoptotic events. With this in mind, we further studied the effect of CA, CI and FA phenolic acids, in DNA damaging, using the micronucleus test and the comet assay as genotoxic end-points.

According to the data obtained in the comet assay, the three acids did not present genotoxicity at any of the concentrations used. In relation to the CA acid, these results are in accordance with the data that one of the major activities of CA is to prevent DNA single-strand breakage and cytotoxic resides (Sestilli et al., 2002). On the other hand, the micronucleus test showed that these same acids present clastogenic effects.

Some assays using bacterial studies in the absence and presence of metabolic activation did not find any evidence of mutagenicity of the CI acid in Salmonella typhimurium (Lijinski and Andrews, 1980; Azizan and Blevins, 1995), some Escherichia coli strains (Kuroda et al., 1984; Yoo, 1986) and by the rec assay test in Bacillus subtilis (Sekizawa and Shibamoto, 1982; Yoo, 1986). There have been no reported mutagenicity and genotoxicity mammalian studies on the CI acid, but there have been several on its precursor, cinnamaldehyde, some of which show positive results (see Bickers et al., 2005, for review).

CA presented a dose-related increase of the micronucleated cells. It is possible that these mutagenic effects may be responsible for the enhancing of carcinogenicity effects observed in a rat medium-term multi-organ model by Hirose et al. (1997). This idea should be investigated in further studies. Clastogenic activity of CA was also reported by Hanham et al. (1983). There have been no previously reported studies evaluating the mutagenic potential of FA in eukaryotic cells. However, there have been some studies that show that FA exhibits anticarcinogenic and anti-ageing effects, which are specifically attributed to its antioxidant potential (Lesca, 1983; Graf, 1992; Kawabata et al., 2000). In our study, we observed clastogenic effects of CA and FA.

There are substances that can present mutagenic and antimutagenic action. Tavares et al. (2006) evaluated the mutagenic and antimutagenic effects of Brazilian propolis, and observed that this complex mixture presents mutagenicity at higher concentrations, while at lower concentrations, it displays a chemopreventive effect on doxorubicin-induced genotoxicity. Comparative chemical analysis of Baccharis dracunculifolia and green propolis demonstrated that Baccharis is the main plant source of propolis produced in the cerrado or savannah region in the south of Minas Gerais, Brazil (Park et al., 2004). Flavonoids have been suggested as the components largely responsible for both the mutagenic and antimutagenic effects of propolis, since these compounds can act either as pro-oxidants or as free radical scavengers, depending on their concentration (Tavares et al., 2006). Baccharis and propolis have similar constituents (Park et al., 2002, 2004) and between them there are some phenolic compounds, as well as FA and CI acids and their derivatives, including CA. According to Munari et al. (2010), studies designed to isolate, indentify and characterize the compounds of B. dracuncu- 
lifolia and propolis should provide a better understanding of the genotoxic and antigenotoxic mechanisms observed on both complex extracts. Therefore, the results obtained in our study enabled us to correlate the compounds analyzed here with the mutagenic effects observed in Baccharis and propolis (Tavares et al., 2006; Resende, 2008; Munari et al., 2010), e.g., once these extracts present CA, CI and FA on their composition and also showed mutagenic effects only in higher doses.

Despite the fact that phenols constitute one of the widest marketed groups of dietary supplements, and the lack of studies on their genotoxic effects in higher organisms, some have shown mutagenic effects in mammalian cells, such as tannic acid (Ferguson et al., 1985), coumarin, vanillin, caffeine, tannic acid, and cinnamaldehyde (Sanyal et al., 1997). In the present study, the three phenolic acids tested showed no genotoxicity in HTCs by the comet assay. However, in the micronucleus test, clastogenicity was observed for all the compounds. The comet assay detected primary DNA damage. While the formation of DNA adducts or strand breakage is often the first step in mutation induction, this damage can also be repaired (Brendler-Schwaab et al., 2005). On the other hand, the micronuclei observed in the micronucleus assay are usually formed from loss of chromosomal fragments during the division of the nucleated precursor cells (clastogenic effects) (Salamone et al., 1980). Micronuclei may also be formed if whole chromosomes are lost (aneugenic effects), and this type of mutation is not detected by the comet assay. Our micronucleus data indicate that CA, FA and CI phenolic acids produce clastogenic effects on HTCs. Our NDI analysis evidenced no cytotoxic effects on HTCs of the phenolic acids tested. Since the phenolic acids studied here exhibit a wide range of therapeutic properties, caution is needed with the intake of high or cumulative doses of these compounds and the risk of lower doses to human health needs to be better established.

\section{ACKNOWLEDGMENTS}

We would like to thank the Brazilian agencies CNPq (\#306544/2006-7) and FAPESP - Fundação de Amparo à Pesquisa do Estado de São Paulo (\#2006/57514-2) for their financial support for this study.

\section{REFERENCES}

Azizan A and Blevins RD (1995). Mutagenicity and antimutagenicity testing of six chemicals associated with the pungent properties of specific spices as revealed by the Ames Salmonella/microsomal assay. Arch. Environ. Contam. Toxicol. 28: 248-258.

Bickers D, Calow P, Greim H, Hanifin JM, et al. (2005). A toxicologic and dermatologic assessment of cinnamyl alcohol, cinnamaldehyde and cinnamic acid when used as fragrance ingredients. Food Chem. Toxicol. 43: 799-836.

Brendler-Schwaab S, Hartmann A, Pfuhler S and Speit G (2005). The in vivo comet assay: use and status in genotoxicity testing. Mutagenesis 20: 245-254.

Burke TR Jr, Fesen MR, Mazumder A, Wang J, et al. (1995). Hydroxylated aromatic inhibitors of HIV-1 integrase. J. Med. Chem. 38: 4171-4178.

Chung TW, Moon SK, Chang YC, Ko JH, et al. (2004). Novel and therapeutic effect of caffeic acid and caffeic acid phenyl ester on hepatocarcinoma cells: complete regression of hepatoma growth and metastasis by dual mechanism. FASEB J. 18: 1670-1681.

Eastmond DA and Tucker JD (1989). Identification of aneuploidy-inducing agents using cytokinesis-blocked human lymphocytes and an antikinetochore antibody. Environ. Mol. Mutagen. 13: 34-43.

Ferguson LR (2001). Role of plant polyphenols in genomic stability. Mutat. Res. 475: 89-111.

Ferguson LR, van Zijl P, Holloway WD and Jones WT (1985). Condensed tannins induce micronuclei in cultured V79 
Chinese hamster cells. Mutat. Res. 158: 89-95.

Fulcher RG (1983). Fluorescence Microscopy of Cereals. In: New Frontiers in Food Microstructure. American Association of Cereal Chemists, Ottawa, 167-175.

Fung VA, Cameron TP, Hughes TJ, Kirby PE, et al. (1988). Mutagenic activity of some coffee flavor ingredients. Mutat. Res. 204: 219-228.

Graf E (1992). Antioxidant potential of ferulic acid. Free Radic. Biol. Med. 13: 435-448.

Greenaway W, Scaysbrook T and Whatley FR (1987). The analysis of bud exudate of Populus x euramericana, and of propolis, by gas chromatography-mass spectrometry. Proc. R. Soc. Lond. Biol. Sci. 232: 249-272.

Grunberger D, Banerjee R, Eisinger K, Oltz EM, et al. (1988). Preferential cytotoxicity on tumor cells by caffeic acid phenethyl ester isolated from propolis. Experientia 44: 230-232.

Hanham AF, Dunn BP and Stich HF (1983). Clastogenic activity of caffeic acid and its relationship to hydrogen peroxide generated during autooxidation. Mutat. Res. 116: 333-339.

Hirose M, Takesada Y, Tanaka H, Tamano S, et al. (1997). Carcinogenicity of antioxidants BHA, caffeic acid, sesamol, 4-methoxyphenol and catechol at low doses, either alone or in combination, and modulation of their effects in a rat médium-term multi-organ carcinogenesis model. Carcinogenesis 19: 207-212.

Kanski J, Aksenova M, Stoyanova A and Butterfield DA (2002). Ferulic acid antioxidant protection against hydroxyl and peroxyl radical oxidation in synaptosomal and neuronal cell culture systems in vitro: structure-activity studies. $J$. Nutr. Biochem. 13: 273-281.

Kawabata K, Yamamoto T, Hara A, Shimizu M, et al. (2000). Modifying effects of ferulic acid on azoxymethane-induced colon carcinogenesis in F344 rats. Cancer Lett. 157: 15-21.

Kobayashi H, Sugiyama C, Morikawa Y, Hayashi M, et al. (1995). A comparison between the manual microscopic analisys and computerized image analisys in the single cell gel electrophoresis. MMS Commun. 3: 103-115.

Kuroda Y, Yoo YS and Ishibashi T (1984). Antimutagenic activity of food additives. Mutat. Res. 130: 369.

Lesca P (1983). Protective effects of ellagic acid and other plant phenols on benzo[a]pyrene-induced neoplasia in mice. Carcinogenesis 4: 1651-1653.

Lijinsky W and Andrews AW (1980). Mutagenicity of vinyl compounds in Salmonella typhimurium. Teratog. Carcinog. Mutagen. 1: 259-267.

Mosmann T (1983). Rapid colorimetric assay for cellular growth and survival: application to proliferation and cytotoxicity assays. J. Immunol. Methods 65: 55-63.

Munari CC, Alves JM, Bastos JK and Tavares DC (2010). Evaluation of the genotoxic and antigenotoxic potential of Baccharis dracunculifolia extract on V79 cells by the comet assay. J. Appl. Toxicol. 30: 22-28.

Natarajan AT and Darroudi F (1991). Use of human hepatoma cells for in vitro metabolic activation of chemical mutagens/ carcinogens. Mutagenesis 6: 399-403.

Natella F, Nardini M, Di Felice M and Scaccini C (1999). Benzoic and cinnamic acid derivatives as antioxidants: structureactivity relation. J. Agric. Food Chem. 47: 1453-1459.

Park YK, Alencar SM and Aguiar CL (2002). Botanical origin and chemical composition of Brazilian propolis. J. Agric. Food Chem. 50: 2502-2506.

Park YK, Paredes-Guzman JF, Aguiar CL, Alencar SM, et al. (2004). Chemical constituents in Baccharis dracunculifolia as the main botanical origin of southeastern Brazilian propolis. J. Agric. Food Chem. 52: 1100-1103.

Resende FA (2008). Estudo da Atividade Mutagênica e/ou Antimutagênica da Baccharis dracunculifolia em Células de Mamíferos in vivo e in vitro. Dissertação de Mestrado, Universidade de Franca, Franca, 95.

RIFM (1976). Acute Oral Toxicity Study in Rats and Acute Dermal Toxicity Study in Rabbits. RIFM Report Number 2023, August 18, Woodcliff Lake, New Jersey.

RIFM (1997). Acute Dermal Toxicity Study in Rabbits. RIFM Report Number 29438, January 28, Woodcliff Lake, New Jersey.

Salamone M, Heddle J, Stuart E and Katz M (1980). Towards an inproved micronucleus test: studies on 3 model agents, mitomycin C, cyclophosphamide and dimethylbenzanthracene. Mutat. Res. 74: 347-356.

Salvadori DM, Ribeiro LR and Natarajan AT (1993). The anticlastogenicity of beta-carotene evaluated on human hepatoma cells. Mutat. Res. 303: 151-156.

Sanyal R, Darroudi F, Parzefall W, Nagao M, et al. (1997). Inhibition of the genotoxic effects of heterocyclic amines in human derived hepatoma cells by dietary bioantimutagens. Mutagenesis 12: 297-303.

Sekizawa J and Shibamoto T (1982). Genotoxicity of safrole-related chemicals in microbial test systems. Mutat. Res. 101: 127-140.

Sestili P, Diamantini G, Bedini A, Cerioni L, et al. (2002). Plant-derived phenolic compounds prevent the DNA singlestrand breakage and cytotoxicity induced by tert-butylhydroperoxide via an iron-chelating mechanism. Biochem. $J$. 
364: 121-128.

Sokal RR and Rohlf FJ (1995). Biometry. W.H. Freeman, San Francisco, 175-205, 404-486.

Soobrattee MA, Neergheen VS, Luximon-Ramma A, Aruoma OI, et al. (2005). Phenolics as potential antioxidant therapeutic agents: mechanism and actions. Mutat. Res. 579: 200-213.

Speit G and Hartmann A (2005). The comet assay: a sensitive genotoxicity test for the detection of DNA damage. Methods Mol. Biol. 291: 85-95.

Sri BM, Rukkumani R and Menon VP (2003). Protective effects of ferulic acid on hyperlipidemic diabetic rats. Acta Diabetol. 40: 118-122.

Srinivasan M, Sudheer AR and Menon VP (2007). Ferulic acid: therapeutic potential through its antioxidant property. $J$. Clin. Biochem. Nutr. 40: 92-100.

Tavares DC, Mazzaron Barcelos GR, Silva LF, Chacon Tonin CC, et al. (2006). Propolis-induced genotoxicity and antigenotoxicity in Chinese hamster ovary cells. Toxicol. In Vitro 20: 1154-1158.

Tice RR, Agurell E, Anderson D, Burlinson B, et al. (2000). Single cell gel/comet assay: guidelines for in vitro and in vivo genetic toxicology testing. Environ. Mol. Mutagen. 35: 206-221.

Titenko-Holland N, Windham G, Kolachana P, Reinisch F, et al. (1997). Genotoxicity of malathion in human lymphocytes assessed using the micronucleus assay in vitro and in vivo: a study of malathion-exposed workers. Mutat. Res. 388 : 85-95.

Uhl M, Helma C and Knasmuller S (1999). Single-cell gel electrophoresis assays with human-derived hepatoma (Hep G2) cells. Mutat. Res. 441: 215-224.

Uhl M, Helma C and Knasmuller S (2000). Evaluation of the single cell gel electrophoresis assay with human hepatoma (Hep G2) cells. Mutat. Res. 468: 213-225.

Yoo YS (1986). Mutagenic and antimutagenic activities of flavouring agents used in foodstuffs. J. Osaka City Med. Center 34: $267-288$. 